\title{
女子の Sphincterometry
}

\author{
東京医科歯科大学泌尿器科教室 \\ (落合京一郎教授) \\ 斉藤 \\ 博
}

\section{SPHINCTEROMETRY OF THE FEMALE URETHRA}

\author{
Hiroshi Saito \\ Department of Urology, Tokyo Medical \& Dental University
}

(Prof. K. Ochiai)

A new device for sphincterometry of the female urethra is described: a water tank, a piston pump, a variable microcock, a flow-meter, and an urethral adapter with cone-shaped tip are attached to an autorecording manometer. The tonus of the external urethral sphincter, strictly speaking the intraurethral pressure is measured and recorded, while water is flowing through the urethra under constant flow rate $(50 \mathrm{cc} / \mathrm{min})$.

Sphincterometrograms were analysed by two elements; tonicity (height of pressure) and wave pattern. Sphincterometrogram in the healthy female shows $40-80 \mathrm{mmHg}$ of tonicity with regular wave pattern; in children it is slightly hypotonic. In complete incontinence it is very hypotonic with flat wave pattern. In stress incontinence the sphincterometrogram is similar to complete incontinence, but cases which are hypertonic, always are complicated with inflammation of the bladder neck. In neurogenic bladder after hysterectomy it is slightly or very hypotonic with almost flat wave pattern, whereas cystometrogram is very hypertonic. The neurogenic bladder symptom after hysterectomy is of a special type, which is not purely defined to be a atonic bladder nor a sensory neurogenic bladder, but seems rather to be a combinred form of stress incontinence and over-flow incontinence. Enuresis shows normal sphincterometrogram. In uninhibited bladder it is hypertonic with special wave pattern. In contracted bladder it is very hypertonic with flat wave pattern.

\section{I. 緒言}

排尿機能検查法の一つに膀胱内圧測定法 (cystometry）がある. 只の測定法に関する研究もすでに内外にお いて数多く発表されすすでに routine の臨床検査法とし て常用されている (Rose, 1927 : Lewis, 1935 : Munro, 1936 : Mc Lellan; 1939 : Murphy, 1960 : 佐藤, 1940: 伊丹, 1945：中島, 1960 : 中野, 1963なぞ).

しかし、排尿の機構に参与する重要な要素としてはさ らに内尿道口部あるい外括約筋部などがある。したが つて，さらに正確を期するために忙，てれらの機能をも 険査するととの必要が痛感される化至り，いわ的括約 筋力測定法 (sphincterometry) というととがとりあげ られたわけである.ただ，との sphincterometry は膀 胱内圧測定法にくらべると，いくつかの困難を伴つてい る. そのためか, 乥の重要性と必要性が認識されていな がら，よい測定法が考案確立されず，したがつてその測 定成績なごにも疑義がもたれたりして，あまり目立つた
研究が行われていなかつたようである。最近に至つてと れ関するいくつかの報告が見られるようになつた。こ れまでに考案されたこれらの測定法注原理的に 2 つに大

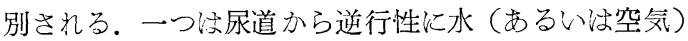
を注入してその示す圧力を測定する方法であり，もう一 つ经特別に作つたバルン・カテーテルを内尿道口部に位 置させ、バルンにかかる圧力を測定する方法である。た とえ法，具体的に㤌それぞれ多少ちがつているが Fartl (1953) Plater (1958), Beck (1961), Thirmann(1951) などのそれ治前者の測定法, Enhöhrning (1960),Emanuel (1963),なぞの方法惊後者の測定法の代表的なもの である.本邦で用いられている測定法も主として後者で ある(佐藤, 1941 : 猪野毛, 1964など).どちらの測定法 がすぐれているか纺，原理的とも実施上でもそれぞれ一

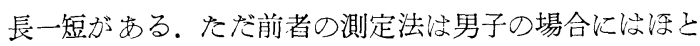
んど応用できない (後章を参照).

著者もがが䄈との sphinctrometry の必要性を感 
じていたので，一応女子学対象とした sphincterometry 等企図し，Thiermann または Beck らの坊法に準じ て次章优述がるな測定装置を考案作製し，この測定

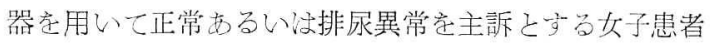
の spincterometry 学行つた。 その結果，この小うな 測定法が臨末的に十分使用できるものであること等確め 得, ま各種の排尿異常症の診断にち役立つという成績 在得左。

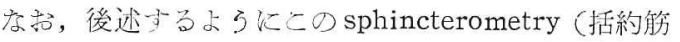
力測定法）という用語は必ずしも適当ではなく，別汇尿 道抵抗測定法上か, 尿道内止測定とょんでいる人もい る.しかし, 著者は慣用に従つて本論交ではとの sphincterometry しいう言葉学使用するととにした。

\section{II. 測定装置と測定法}

(A) 測定器具

著者の使用した测定器の原理は Thiermann (1951) 㧍よび Beck (1961) のそれ々同様であるが，でをるだ

第 1 図 Sphincterometry 用装置
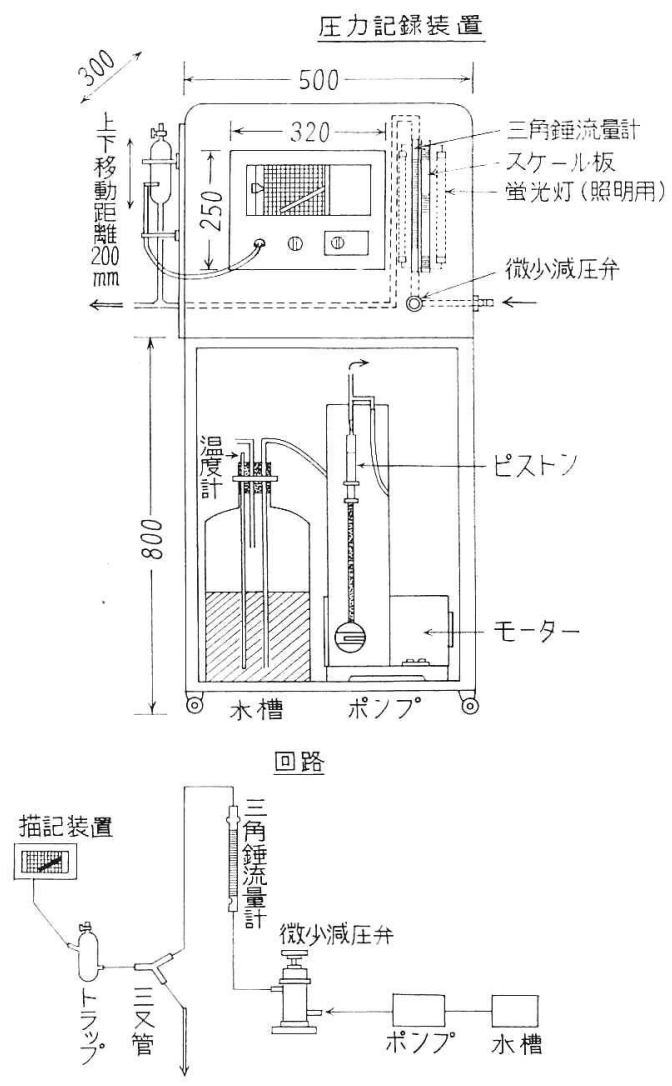

第 2 図 Sphincterometry 用装置

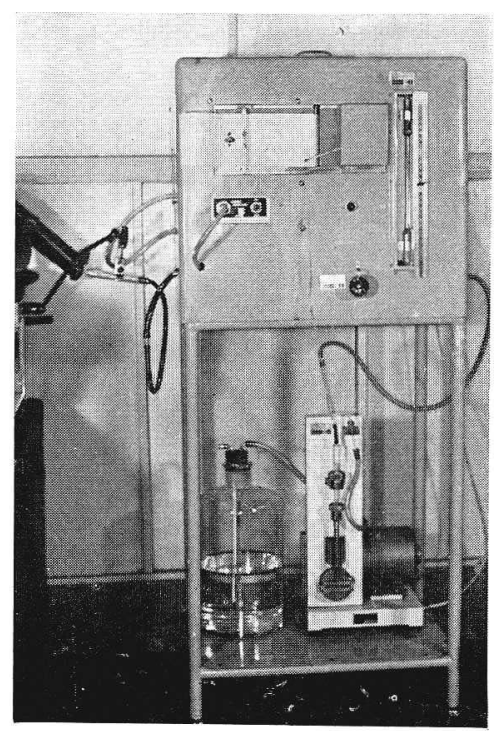

第3図 Sphincterometry用のスポイト（嘴管）と その保持器

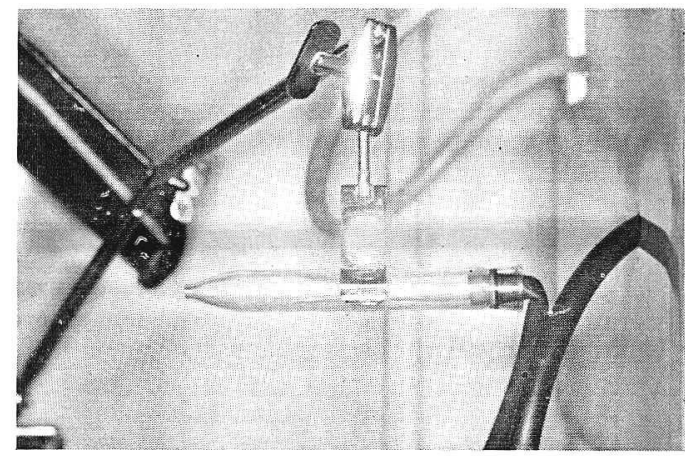

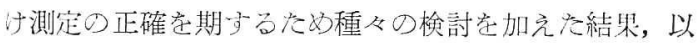
下に述べるょらな測定器具学作製して使用した（第1， 第 2 , 第 3 図参照). 杂ず使用子方減菌水 (水溶性マーソ ニンを混入)悢，これを蓄える水槽の中の寒䐘計によつて

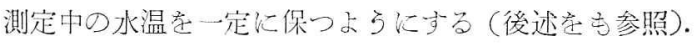
との水槽からポンプ（後述）で水在く羊上げ, 流量計拉 よび微少流量調整器によつて流速（流是）军調節しなが らトラップを通じて流し, 一方心連続自動記録器に, 他

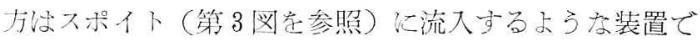
ある。

Beck の測定法沈，女子の外尿道口に密着できるよう な觜管定字つ特殊なスポイト (urethraladaptor) 尊外尿 
第 4 図 注水压と実測値との関係

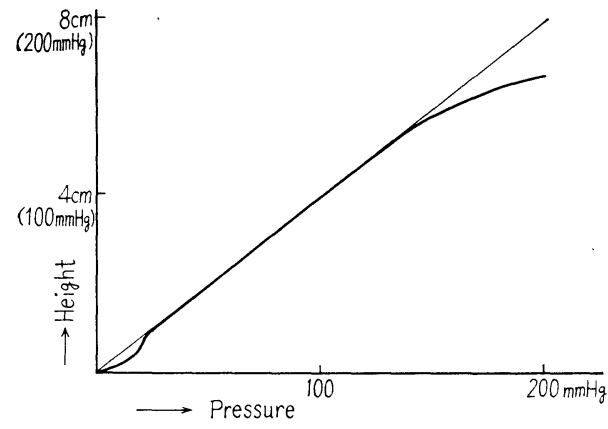

道口に当て，別に注射針を通じ每分約50ccの流速になる ようにして (約 $200 \mathrm{~mm} H \mathrm{~g}$ の圧力), 水学とのスポイトから 尿道内に注入するょうにしとの水圧を三差管およびトラ ップを介して自動記録器に連結して, その圧力を測定す るものである. Beck はその論文の中で，とのようにし て水学尿道内に注入する場合, 尿道内の圧力の上昇に伴 つて当然流速が減少していくわけであるが，との点は一 応無視していると断つている.

著者はまず記録器としては連続自動記録装置を用い た. この連続自動記録器 (ベロー式) はペン書き（イン ク使用) で, 紙速抙毎分 $1.25 \mathrm{~cm}(0.5 \mathrm{inch})$, 用紙の長さ $100 \mathrm{~m}$, 描記できる圧力の範囲は 0〜 200 mm Hgである.

以下に述べるょうに, sphincterometsy に当つての圧 力は㟫ぼ10〜 120 mm Hgの範囲内にある. 念のため記録器 の感度を検查してみると, 第 4 図のよらなグラフを示 し, 10〜 120mmmg正常範囲内では应とんご直線である ととを確認した.

次に流速の点である. 上述のように Beck は流速の変 化は無視すると断つているが，との方法を追試してみる と尿道内圧の変動に伴う流速の変動は意外に大きく, 流 入をつづけているうちに所定の $50 \mathrm{cc} / \mathrm{min}$ という流量は 漸次低減して,ついには $10 \mathrm{cc} / \mathrm{min}$ 又は $5 \mathrm{cc} / \mathrm{min}$ と落与 ていく．とれを流速に関しての誤差に換算すると $80 \%$ 氻 ら $90 \%$ も減少になるととを知つた。このような流速, したがつて毎分の流量の聥減も同一の測定器具を使用し た場合の測定值の比較には相殺されてしまうと考えられ るので，一応無視できるともいえる。しかし，とれは sphincterometryに打けるより正確な測定值こはいえな い. そとで著者は sphincterometryに常用される圧力範 囲内で，乙の流量(流速)をできるだけ一定に保つととが できるょうにという目的のもとに，特別にポンプを作製 させて使用した。 その性能と条件は以下のようである.
第 5 図 注水圧と流量との関係

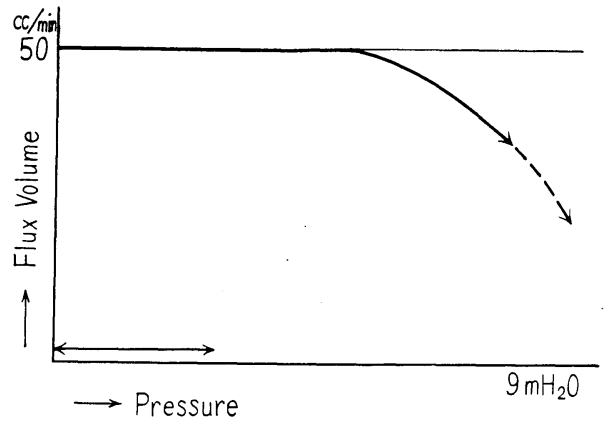

（註）↔は測定に使用される水圧の範囲

輸送方式：単動ピストン, 主要部材質: ガラス, モー ター：インタクション・モーター, 流量範囲：最高一 $300 \mathrm{cc} / \mathrm{min}$. 使用流量 : $50 \mathrm{cc} / \mathrm{min}$. 流量調整：休止中の みストローク長を変えるととで調整する, 調整情度：2 $\%$, 揚：9 $\mathrm{mH}_{2} \mathrm{O}$. 温度：0 $200^{\circ} \mathrm{C}$ まて使用可能（実 施時の温度については後述する).

とのポンプの特性曲線は測定してないが，流量と圧力 との関係を知るために行つた予備実験成績は第 5 図の如 くであつた。すなわち，との成績から著者の意図する sphincterometry に打ける使用範围では添 $50 \mathrm{cc} / \mathrm{min}$ の流量を保持することができる，ただ，乙のポンプは休 止中の及調整が可能なものであるため, とくに直読でき る三角錐流量計 $(0 \mathrm{cc} / \mathrm{min} \sim 100 \mathrm{cc} / \mathrm{min})$ と微小流量調 整器（減圧弁）を加えるととによつて，流入にしたがつ て生ずる圧力の変化に即応してその流量を常に $50 \mathrm{cc} / \mathrm{min}$ に保つととができるょうに工夫してある。ただし，実 際には流水口をなるべく小さくすることによつて, ピス トンポンプだけでも, 変動が少なくてほぶ一定量の水を 流すことができる。したがつて実際には必ずしも常にて の微小減圧弁を使わなくてもすんでいる，むしろ，測定 の間にたびたび微小減圧弁を用いるととはとの種の測定 器の精度としては好ましくない，そこで著者は，測定開 始前に流量を $50 \mathrm{cc} / \mathrm{min}$ に調整する時にだけ利用するに 止めるようにした，ただし，てのポンプを使用しても測 定に当つては接着部などからのごく少量の漏水（たとえ ば尿道と尿道スポイトの間など) が見られるととがあ る. この漏水慎重な測定操作によつてほぼ完全に防止 し得るし，たとえ少量の漏水があつてもそれは $50 \mathrm{cc} / \mathrm{min}$ の流量に対しては多くて士5.0cc 程度である. つまり 多くても土10\%の誤差であり，てれは sphincterometry 
に際してまず無視できるもので，との器具は十分使用に 耐えるものと考えてよい。

外尿道口に接着させる嘴管（スポイト，あるいはアタ プター）は，Beck が使用した器具と全く同様のものに よつた（第 3 図）.とのスポイトの先端を正しく外尿道口 に密着させる. 測定の間にとの位置が変動しないように 保持器で固定する（短時間なら手で保持してもよい，第 3 図参照).いずれにしろ，スポイトの先端の開口が正確 に外尿道口の方向に一致して括り，周囲から漏水がない 程度の圧迫で密接しているょうに常に注意するととが絶 対に必要である.とのスポイトはもちろん消毒可能であ る. この測定器は閉鎖系 (closed system) にしておき. 測定実施の前後にはマーゾニン水を流して消毒する.

この測定器具を使い易いょうに一つのキャビネットに 収め, 四脚に車をつけて運搬できるょうにした（第 1 図, 第 2 図参照)

(B) 測定法

(1) 水 温

測定にはマーゾニン水（約5,000 倍）を使用した. cystometryでは一般に $37^{\circ} \mathrm{C}$ 温水が使用され, さらに冷 暖などの膀胱感覚の検查に注冷水あるいは $30-40^{\circ} \mathrm{C}$ 温 水も応用される。後述するように，著者はとの測定法に よつて sphincterometry のみならず同時に cystometry を行つているが、主たる検査目的が sphincterometry にあるため，乙の盜度には特別の考慮を払つていな い. しかし，より体温に近い温水の方がよいと考えられ るので，使用する水はできるだけ $37^{\circ} \mathrm{C}$ 前後の温水を使用 した. 一応検查する部屋の室温は一定に保つようにして 測定を行つているが, 多数例の測定経験から, 水槽内の 寒暖計によつて夏なら $40 \sim 50^{\circ} \mathrm{C}$, 冬なら $50 \sim 60^{\circ} \mathrm{C}$ 程度の 温度に保つょうにして打け㜔，流水口に打ける水温は大 よそ $37^{\circ} \mathrm{C}$ 前後であるととを知つた。 な打念のため, 流水 口の水温が $20^{\circ} \mathrm{C}$ あいは $40^{\circ} \mathrm{C}$ もので同一人について sphincterometry 行つて比較したが，との水温のちが いによる測定值の差をまずないととも確め得ており。 sphincterometry に関しては上述した水槽内の水温調 節だけで十分と考えるととができる.

（2）流速㧍よび流量

女子尿道は内胿の閉鎖した筒状のもので，流出口を内 尿道口と考えた場合，ととへ流入させた水の示す圧力に はその水の流速が密接な関係をもつている.したがつ て, 尿道内に水を注入してもその圧力を測定するにはな ず流速をできるだけ一定にして行わなくてはその測定值
の比較はできない，上述のょろな測定装置を工夫し作製 した目的の一つもとの点にある.

実際にそれぞれ $20 \mathrm{cc} / \mathrm{min} .50 \mathrm{cc} / \mathrm{min} .80 \mathrm{cc} / \mathrm{min}$ の流速 (流量)で行つた cystometry および sphincterometryの際の注水圧と流量との関係を示す．グラフは第 6 図 のようになる.すなわち, 流速のちがいによつてかなり 著明な測定值の変動があり，乙れはとくに cystometry においてはつきりしている．いいかえると，流速の速 いもの（毎分の流量の多いもの）漂と測定值は高く、遅 いもの(毎分の流量の少いもの)などその測定值は低い. との流速をいろいろに変えて cystometry 行い, そ の描がかれた内圧曲線のちがいによつて膀胱の機能を調 べるととも可能であり，実際にもとの原理を利用したと 思われる測定法, cystoadaptmetry という測定法があ り，その有用性に関する研究なぞも行われている. (Arnold, 1959 ：近藤, 1964なぞ). しかし, 後述のように著 者作製の測定装置のポンプではまだ容易に，正確にこの ような大巾の流速の変動を行らことができず（実際にも 著者の利用した微小減圧弁では，それほど大巾に流量を 変えることは不可能), また主をる研究目的が sphincterometry にあつたため, ポンプ・ストロークばー定にし ておき，測定にはこの流速で測定を行つたものである。 なお, Enhöhrning (1961) は特に考案した装置を利用 して cystometry および sphincterometry 同時に行 う方法を発表している。 とのような測定法の方がよいか ぞうかは別問題として, 著者の行つた測定法でも同じ膀 胱容量時の cystometry と sphincterometry の照合は 簡単に行うことができる(後述).

著者はとの一定の流速（流量）として毎分50ccを用い た.との流速は一般に cystometryの場合に常用される 流速である、したがつて，との流速は任意にきめたもの

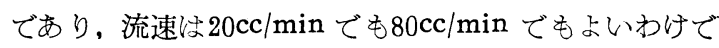
ある (第 6 図参照). しかし著者の cystometry ncterometry 同時に行うという点も考慮して，測定 時の流速を $50 \mathrm{cc} / \mathrm{min}$ としたものである（第 5 図，第 6 図参照).な打既述のように Beck もとの50cc/min の流 速で sphincterometry 行つている.（ただし，実際に はもつと少ない流量になつている。）

(3) 測定の実施

患者の検診台の上にのせる. まず測定器内を通水させ て調整を行う。それにはトラップをほぼ外尿道口と水平 の位置にしてから、スポイトを外尿道口のそばまでもつ ていつて基線を定める. 次にとのスポイトを外尿道口に 
第 6 図（正常例）35才 流速と cystometrogram および sphincterometrogram との関係

(i) $80 \mathrm{cc} / \mathrm{min}$

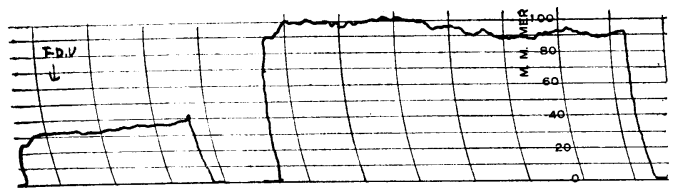

cystometrogram sphincterometrogram

(ii) $50 \mathrm{cc} / \mathrm{min}$

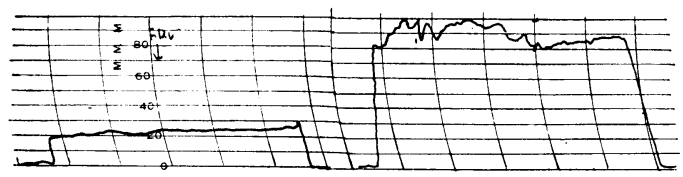

cystometrogram sphincterometrogram

(iii) $20 \mathrm{cc} / \mathrm{min}$

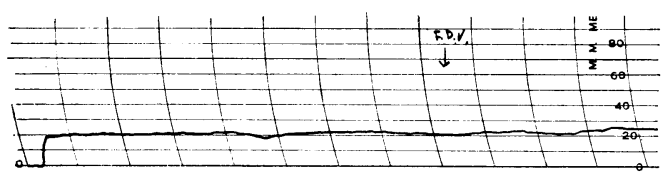

cystometrogram

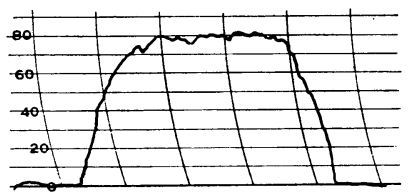

sphincterometrogram

正確に当てて測定を開始する。 な抢 sphincterometry を行う前後には，必ずとの状態と条件のま宗で cystometry を行つた。

しかし，測定の実施に当つてはそのほかにもいくつ加 の注意が必要である。具体的には次のような点に注意す れば, 浇とんぞ常に測定を正確にかつ順調に行うことが できる、その一つ袮スポイトの先端が外尿道口に正しく 適合して扮らないととが往々にして起ることである。そ のためにとの接合部から注入した水が漏れている場合が ある、たとえば、はじめのうち測定はうまくゆき,グラ フも水平に描かれているのに，そのうちこの曲線が急に 下降したりすることがある。これは外尿道口とスポイト 開口との間に多少の間郘が生じていたりして, ことから
少量の水が漏洩したためのととが多い，また逆に，とれ までなめらかに水平のグラフが描かれていたのに, 突然 圧が上昇していく場合もある。乙れはスポイド開口が外 尿道口の方向に正確に一致せず，多少ずれていて尿道壁 に開口部が向いているなどのため水の流入に強い抵抗を 起させたからである。いずれの場合でも，測定中心常に グラフの描出を観察して掞り，急激な測定值の変動が現 われたら、スポイトの位置，角度あるいはスポイトを外 尿道口に当てる圧迫力などを調整しな掞して測定する。 な抢，スポイトを外尿道口に当てる時の力(圧迫の程度) は，スポイトと外尿道口との間から注入する水の漏洩が ない最も最小限の圧迫によつて行うが, 多少強く圧しつ けても測定值には添とんぞ影響はない。

いずれにしろ，スポイト開口から注入される水が順調 に尿道内学通つて膀胱内に入つていきつつあるかどうか を確めるに法，具体的には次のような注意をもとに行え 岒いい，宗ず保持器に装置したスポイト先端をできるだ け正確に外尿道口に当て, 注水して見て漏洩のないとと を確認する．とれが確認されたら．ひきつづき測定を開 始する．直ちに曲線は上昇し，間もなく一定の高さのと ころで潘济水平になつた時, もう一度スポイトを外尿道 口にあてる向き，圧しつける強さなどを調べて測定值が. 一番低い值に落ちつくようにする。乙のま染の位置で更 に数分間測定导つづければよい. 水圧がこのような结涪 一定の高さの值に落ちつけぼ, グラフの描出はかなり安 定したもの々なるからである。スポイトを保持器に装着 しての測定ができない場合は、スポイトを手で把握して 外尿道口に当てて測定するわけであるが，10分以上に及 ぶとどうしても位置がずれたり，圧迫が弱くなつたりし て、よいグラフが得られないととが往々ある。したがつ て、万一やむを得ない場合至除き，原則としてはスポイ 卜を保持器㳖着して測定する。またまれには測定に 際し注水と同時に強い疼痛索訴えて測定が不可能なとと もないではない，麻酔をして行えばよいわけであるが， 麻酔が sphincterometry に対し全く無影響とはいえ ず、グラフの分析活困難となるととが予想されるので (後章を参照), 著者は原則としてすべて無麻酔で測定し た.

このような sphincterometry というものは同じ原理 で男子にも応用できるはずである，実際にも著者のよう なスポイト，または尿道カテーテルとかを利用した男子 の sphincterometry（正確には尿道抵抗, urethral re- 
sistance の測定）をしょうという試みとか，とれに関 する論交も少くない (Bors, 1948 ：土屋,1963など). 著者 も上述した測定装置によつて男子について測定を試みて 見た．しかし，多くは測定中にかなり強い尿道部の疼痛 を訴えて測定不可能になつたり，そうでないものでも著 しく高い測定值が描出されたりして，女子の場合のよう な一定したグラフを得るととははとんど不可能であつ た.したがつて著者のこの装置は男子のsphincterometry には適当ではなく，とれは全く女子の sphincterometry 用の測定装置掞よび測定方法である.

\section{III. 症例と測定成縝}

(A) 測定例とその内訳

検查の対象となつたのは, 1961年から1964年の 4 年間 行東京医科霜科大学泌尿器科を栄診した患者（外来打上

第 1 表 測定を行つた症例数と内訳

\begin{tabular}{|c|c|c|}
\hline (1) & 正常成人 & 40 例（20〜 73才） \\
\hline (2) & 正常女児 & 7 例（ 4 〜 14才） \\
\hline (3) & 真性尿失禁 & 2例 \\
\hline (4) & Stress incontinence & 15例（22〜 62 お) \\
\hline (5) & 神経因性膀胱 & 39 例（43〜 69 お） \\
\hline (6) & 夜尿症 & 2 例 \\
\hline (7) & 無抑制膀脱 & 3例 \\
\hline (8) & 膀胱炎 & 4例（18〜 49才） \\
\hline (9) & 萎縮膀胱 & 3例 \\
\hline
\end{tabular}

計 115 例

（註）同一人で 2 回以上測定したもの，麻醉による 影響の检索のための測定例もあ $\dot{n}$, 測定回数 としては延 170回以上になつている。

び入院患者）で，著者の測定装置を用いて sphincterometry 行つた症例数は 115名 (4才から73才) でいず れも女子である(第一表参照).測定の回数は約 170 回以 上である。

(B) sphincterometrogram の成績

(1) sphincterometgram の分類と型式

前節で記述したように，著者はまず cystomatry を 行つてから sphincterometry にうつつた. とれは同じ 膀胱容量の時のそれぞれの測定成績を比較するのに便利 だからである，また後述するょうに，一般的にいつて sphincterometrogram は膀胱容量による変化をほとん ど示すととなく、実施の最初から最後までほぼ同じ值を 得ることができた. したがつて, 測定の都合によつて膀 胱が充満するまでsphincterometryを続けられないよう な場合には最少 1 分 (時には 30 秒) 程度の測定值によつ
たものもまれにはあるが測定值の判定には十分と考えら れるものである.な漏水による曲線の下降とかスポイ トの先端が正しく外尿道口にあたつていなかつたための 測定値の上杽などがまれ経験されるが，てれは特有な 急激な昇降線を描くのですぐ判別できるので，かかる曲 線はもちろん除外し, 全体的に水平になつたグラフの部 分を用いている.

以上に述べるょうにとの sphincterometry による測 定值 (以下 sphincterometrogram と記載する) の分析 で重要なものは，（1）測定値の高さ，（2）その上代 描かれる波動（波高, 波型あるいは周波数）こである. この測定值の高さとは，膀胱内圧測定などで用いられて いる緊張度 (tonus) と同じ意味をもつといえるので. したがつて hypertonic (緊張過度), normotonic (正 常), hypotonic (緊張低下) という表現を用いてもよい わけである.もう 1 つ㤝 spincterometrogram の上に 現われる波動である.著者はこれに対し波型拧よび波高 （および周波数）という表現を用いることにした。 これ

第 7 図 sphincterometragram の波型 波型波高 (mmHg) 周波数 (c.p.m)

\begin{tabular}{|c|c|c|c|c|}
\hline I ( 为1型) & $m$ & $4 \sim 10$ & & $4 \sim 7$ \\
\hline II（矛2型） & rur & $10 \sim 15$ & & $2 \sim 3$ \\
\hline III (为3型) & m & $2 \sim 3$ & & $5 \sim 10$ \\
\hline IV (乐4型) & $\longrightarrow$ & $0 \sim 1$ & & 0 \\
\hline$\nabla$ (为5型) & MULM & $10 \sim 15$ & & 8 \\
\hline VI (为6型) & M & $15 \sim 20$ & (并水以上) & 5 \\
\hline
\end{tabular}

については順次説明していくが，ての測定法による sphincterometrogram には水平でほとんご波動を示さない むの，全体として大きな波を描くもの，階段状を示すも のなどがあり，また波の高低や変動などもいろいろで, かなりの多形を示しているものである. 著者は便宜上, この sphincterometrogram の記載法を次のようにした。 すなわち，最高值および最低值をもつて緊張度（tonus）を表わし, 波型は I〜VI型に分類した. (第 7 図). ととにいろ波型 (wave pattern) とは, 測定值がほ ぼ一定の水平位をとつてから，その線上に現われる波動 (水圧の変動) のととである. 著者は実施した sphincterometrogramを種々検討した結果, これを全体として の波の形状から波高打よび周波数という 2 つの要素の組 合せによつてとれを次の 6 個の波型に分類した（第 7 図 
参照).一般的に言えば、I (第 1 型) が sphincterometrogramに抢ける波型の基本型である．II（第 2 型）は Iに準ずるもので，ただそのその波高が I よりも高く周 波数はそれょりも少ない，III（第 3 型）は波高はIにく らべてはるかに小さく、ただし周波数はこれよりも多く なつている.IV（第4 型）は添とんどはつきりした波高 を示さず， sphincterometrogram は一定の高さでほと んご浪济平坦な直線状を呈しているＶ（第 5 型）はか なり高い波高を示し，しかも先がとがつた鋭い形をして 抢り，周波数も比較的多い.VI（第 6 型）沙最も高い波 高を示しているが，その周波数はそれ漂ど多くなく，む しろ緩かな波動形である。もちろん，乙の波型は同一人 に抬ける測定の sphincterometrogram 上で必ずしもそ のどれかだけが単一に現われるとはかぎらない．たとえ ば，I＋II，I＋II， III +IV というょうな組合せも往々 認められる。しかし，このような波型の組合せの sphincterometrogramでも,多くの場合にはそのうちのどれ かの波型が主として描出されているものである。

sphincterometrogram の記載法结次のようにした。 たとえば75－（80）－85mmHg，III 型という表現では平均 $80 \mathrm{~mm} \mathrm{Hg}$ （最低㧍よび最高値の算術平均で，大ていは波型 の基線あたりの高さに相当する) を中心として $2 \sim 4 \mathrm{~mm}$ $\mathrm{Hg}$ の上下差で周波数が $5 \sim 10(\mathrm{cpm})$ の比較的細かい波 型（III型）を描いた sphincterometrogramで，その最低 值彶 $75 \mathrm{~mm} \mathrm{Hg}$ ，最高值 $85 \mathrm{~mm} H \mathrm{Hg}$ でることを示している（第 8 図以下去照).ただし, 本文ではこの平均值 (カッコ の数字) 注便利上省略したものもある.

（2） sphincterometry の成績

(i) 正常女子の sphincterometrogram

ここにいう正常とは，何らの排尿異常を認めず，膀胱 容量法 $300 \sim 500 \mathrm{cc}$, 残尿は全くないかあつても10〜20 cc以下（したがつて膀胱効率，残尿/膀睄容量 $\times 100$ が $5 \%$ 以下), 尿にも特別な所見なく, 膀胱所見に正常なも ののことである. 膀胱内圧曲線 (cystometrogram) も 正常曲線を描いている. Cの方な正常者40名余 (16才 から73才までで，大部分は20４0才代）について測定し た. sphincterometrogram の成績は以下の如くであつ た.

ごく少数の例（後述参照）を除き，との正常女子 40 名 余のほとんどの sphincterometrogram の型式は (1) 50-70 $\mathrm{mm} \mathrm{Hg}$ ，I 型分，（2） $70-75 \mathrm{~mm} \mathrm{Hg} ， \mathbb{I I}-\mathrm{IV}$ 型のい ずれかを示している(第 8 図，第 9 図を参照).すなわ

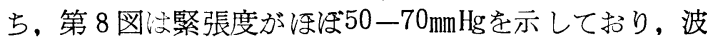

第 8 図正常女子の sphincterometrogram, 38才 55〜 77mmg I 型

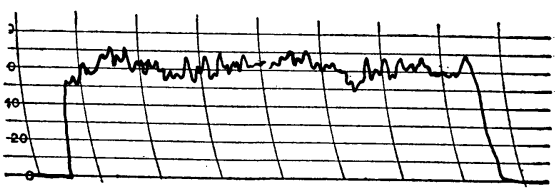

第 9 図 正常女子の sphincterometrogtim, 42才 $70-75 \mathrm{mmHg}, \quad \mathbb{I}-\mathrm{IV}$ 型

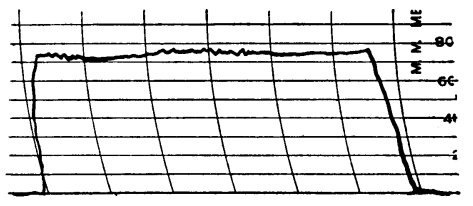

高は $3 \sim 10 \mathrm{~mm} \mathrm{Hg}$ ，周波数は比較的ゆるく 7 c.p.m.のもの であり（I 型）,第 9 図は緊張度が洷 が波高が前者よりも低くて ( $2 \sim 3 \mathrm{~mm} H \mathrm{Hg})$ 周波数は 5 〜 10c.p.m. とやや多い加，一部に添とんど波高の差を示さ ない部分を伴つているものである (III $-I V$ 型). 正常女子 の sphincterometrogram では40例のうち上述のどちら かを示すものが 33 例と浇とんど全部を占めている（II 型 は 5 例，IV 型注 2 例).いいかえると第 8 図あるい以第 9 四に示すよらな型式が正常 sphincterometrogram であ ると考えてよい，1〜2例に执いては，90〜 $100 \mathrm{~mm} \mathrm{Hg}$ いう高い值あるいは逆に35-50 $\mathrm{mm} \mathrm{Hg}$ という低い值を示し たものもあつたが，むしろ例外的であつた。 したがつて sphincterometrogram における測定値が40 $80 \mathrm{~mm} H \mathrm{~m}$ の 間にあるものは正常，つまり normotonic だと見てよ

第10図 正常女子の sphincterometrogram の分布

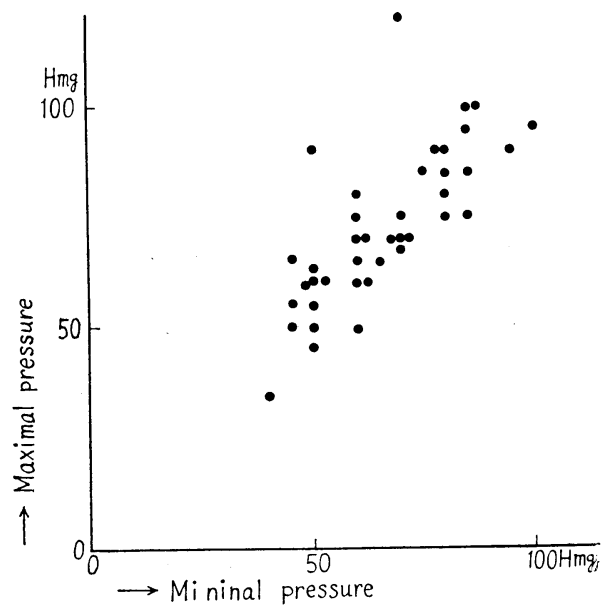


いことになる.もちろん上述のようにごくまれには sphincterometrogramから緊張過度 (hypertonic) ある 注緊張低下 (hypotonic) と考えられるものもないわけ いではないが, 正常の基準としては測定值を上述の範囲 か, せいぜい35〜90m Hgの範囲に置くことができるであ ろう.第10図はこの関係を示したものである.

正常な sphincterometrogram の波型は大部分が I 型 あるいは刑を示していた。（I 型22例，III 型11例、II

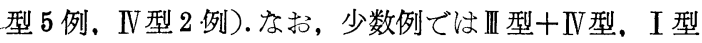
十III 型の混合型と判定した方がよいものもあつたが、一 般的にいえば正常な sphincterometrogram の波型とし てはあまり著明な波高の変動を示さないI 型，あるいは

III型（とくにI 型）を示すと考えてよい.

(ii) 正常女児の

一応15才以下のものを小児例とした. 症例は 7 例で年 令は 4 才〜14才である. このうち 6 才拉よび 4 才のそれ ぞれ 4 例は協力的でなく正確な測定は不可能で，実際に 測定できたのは 3 例（14才，13才，10才）だけであつ た.とれらの sphincterometrogram は30〜 $50 \mathrm{~mm}$ Hgある いは $40 \sim 60 \mathrm{~mm} \mathrm{Hg}$ と成人女子のそれに比して一般に低值を 示しており，波型もどちらかといえば平坦である傾向を 示している．な扮測定不能だつた 2 例については別にう ボナール麻酔下に sphincterometry を行つているが,こ れについては別項で述べるととにする.

(iii) 真性尿失禁の sphincterometrogram

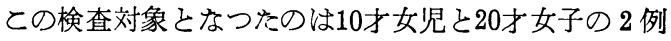
である.

第 1 例は発育不全腎を伴つた同測の尿管の臸内開口例 で. 腎尿管剔除の際にあるいは膀胱頝部を損傷したため 胁, 腔からの尿漏洩は消失したが潘とんぞ完全な尿失禁 を残しているものである. 本例に抢ける sphincteromretrogram $は$ 15-20mnHg と高度の緊張低下 (hypotonus) を示して抢り，波型は不規則でむしろ平坦てあり恐らく IV 型と判定してよいものである. (第11図参照).

第 2 例情春䯣溜 (meningocell) の手術後に発生した 完全尿失禁の症例である. 本例の sphincterometrogr-

第11図 真性尿失禁，10才女児，15～20mmHg，IV型

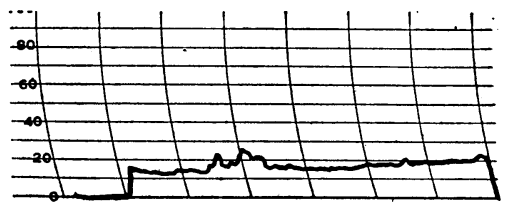

第12図 真性尿失禁，20才女，20一（25）-35 mm Hg， IV 型

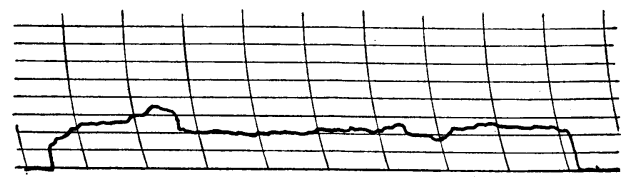

am も20一（25）-35m Hg と著明の緊張低下を示してお り，その波型はやはり不規則な波高の変動を呈している が、全体としては叙とんど上下差のない平坦なもので第 1 例と同じょうに $\mathrm{N}$ 型に属する波型とみるととが出来る (第12図参照).

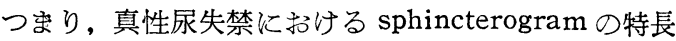
は，著明な緊張低下 (30mm Hg以下) と湾乞んど波高の変 動を呈さない(変動があつても不規則な丘陵状の上下) 平坦な波型を示している点にあると考えられる.

(iv) stress incontinence $の$ sphincterometrogram stress incontinence とは，主として腹圧の高まる動 作（せき，いきみ，急な立ち上がり，重いものをもつな ぞ）によつて不随意に尿这漏洩するものと定義する（い わゆる部分的尿失禁). との症例は15例（22才から62才， 大部分は40〜50才代), 3 例を除き他はいずれも経産婦で ある. これらの症状の程度は種々で，どく少量の尿を失 禁するものから，かなり多量の尿漏洩を起すものなどが あるが，全般的にいうと stress incontinence として沈 比較的軽症に属するものが過半数の11例, 中等症 3 例, かなり重症と考えられるもの1例である.

これら症例の sphincterometrogram 程度によるものと考えられるが，かなりいろいろな型式 を示している. 比較的軽淀のものでは最高值が $40 \sim 50 \mathrm{~mm}$ $\mathrm{Hg}$ ，多くは50〜 60 mm Hg という緊急度を示すものが11例と 大部分を占めている．したがつて最低值は浪㜔正常值範 囲内にあるが，最高値はせいぜい60 $\mathrm{mm} H \mathrm{Hg}$ と正常值のそれ とくらべるとかなり低い值を示しているということがで きる(第13図参照).波型はかなり種々で $\mathrm{I}$ 型 9 例, I 型

第13図 Stress inconinence (軽症)，42才 50～ $55 \mathrm{~mm} \mathrm{mg}, \mathrm{IV}$ 型

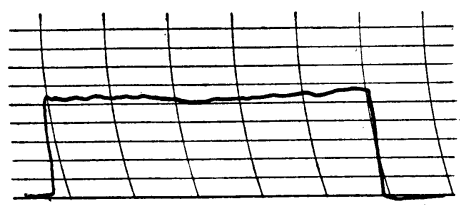


第14図 stress incontinence (軽症)，22才65〜85 $\mathrm{mm} H g, \quad I+\mathbb{I}$ 型

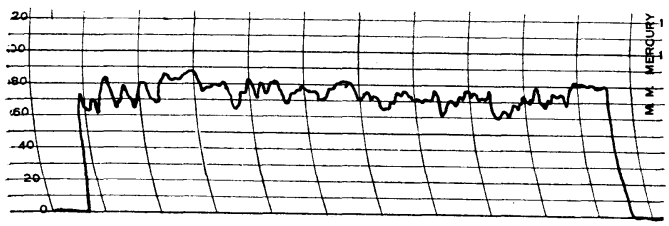

第15図 stress incontinence（重症）３9才，40～ $45 \mathrm{~mm} H g$, IV 型

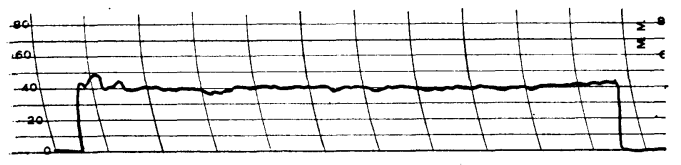

6 例. III 型 4 例, II 型 2 例でどちらかというと波型の平 坦なIV 型が多い（これは測定回数による例数）.だごく 軽症の 1 例では最高值が80 90 mm Hgで波型は I + II 型と いえるものもあつた（第14図参照），てれは正常かむし ろ緊張過度に傾いているが，精査して文るとてのような 症例では程度の差はあるが，膀胱䅡部を中心とする炎症 を伴つていた (後章参照).とれに対し, かなり重症の 1 例では最高值 $45 \mathrm{~mm} \mathrm{Hg}$ と低く，その波型も IN 型と平坦で, これは前述した真性尿失禁のそれに近い sphincterometrogram を示している(第15図参照).

（v）神経因性膀胱（広沉性子宮剔除術後）の sphincterometrogram

子宮癌のために広沉性子宮剔除を施行された後にはか なり高率に膀胱機能障害を続発するものである．その症 状㤃必ずしも一定していないが相当に強い排尿困難（残 尿を呈する), 尿意 (膀胱充満感) の欠如などを訴えるも のが多く，なかには奇異性尿失禁 (overflow incontinence）と考えられる主訴をもつのもいる。.とのようなも の39例（43才加ら69才）に対して sphincterometry 行つた.

症例の詳しい内訳けは排尿困難がごく軽度のもの8 例, かなり高度のもの 25 例, 奇異性尿失禁を主たる症状 とするもの 6 例である.

かかる患者の sphincterometrogram注実際にはかな り多様であつた。これは恐らく膀胱機能障害の程度。あ るいは併発しやすい膀胱炎の存在なぞも関係していると 思われる，たとえばなかには最高值が70〜80 $\mathrm{mm} H$ とほぼ 正常に近いものも約 $1 / 3$ 《認められている（1例では90 $\mathrm{mm} H \mathrm{~g}$ 以上とむしろ明らかに緊張過度のものがあつた（第
第16図 神経因性膀胱（子宮剔除後），55才，80～ $100 \mathrm{~mm} H g$ ， I 型

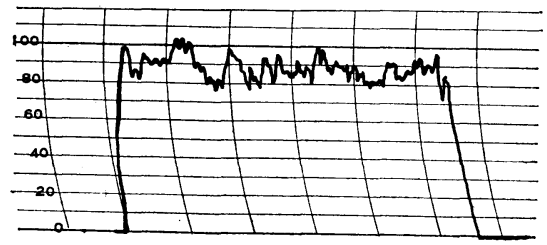

第17図 神経因性膀脱（子宮剔除後), 63才，40４5 $\mathrm{mmHg}, \mathrm{I}$ 型（波型はむしろ平坦）

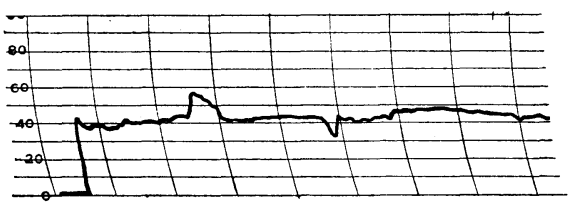

第18図神経因性膀胼（子宮剔除後）, 50 才 $38 \sim 45 \mathrm{~mm}$

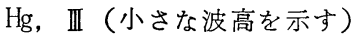

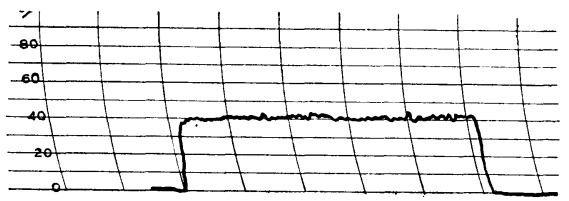

第19図 神経因性膀脱（子宮剔除後），50才５0～ (60) 65mm Hg, I + IV 型（や>大きい波 型)

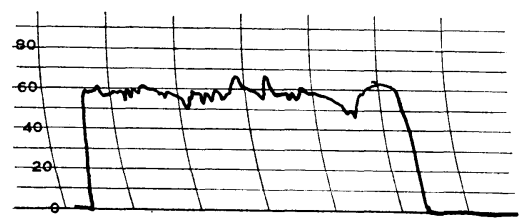

16因参照).しかし，全般的にいうと40～60 mm Hgを示すも のが過半数で，どちらかといえば正常の sphincterometrogram に比してや>毉張低下 (hypotonic) を示卞傾 向がある．また波高についても，正常のそれとちがい， 波高は $3 \mathrm{~mm} \mathrm{Hg}$ 以下が㴗とんぞ平坦に近い波型を示すもの が大部分であつた．ただてれら症例の検査を通じ，特徴 的ともいえるととは sphincterometry 実施中の圧の動 摇が非常に少なく, したがつて測定が非常に容易でその 測定值も一定なものが多いという点であつた。すなわち この群では波型がIV 型のもの35例，I 型が 9 例， II 型が 6 例で II 型は 1 例にも見られない（この例数は測定回数 による).代表的な sphincterometrogram を示すと第16 図、第17図、第18図、第19図のようである。つまり、広 
範性子宮剔除術後に続発しやすいいわゆる神経因性膀睄 の sphincterogramは, どちらかといえば緊張低下（最 高值の低下) の方に寄つたものというととができる. そ れなのになぜ多くは排尿困難を訴えるか，てれについて の膀胱内圧曲線との関係は後章で考察する.

(vi) 夜尿症の sphincterometrogram

既述のように，数才以下の女児では，そのままで sphincterometryを行うことは非協力的なためほとんど不 可能か, たとえ強行してもその成績流極めて不確実であ つた. したがつて, 著者が検査対象にした夜尿症は14才 および20才の女子の 2 例だけである.どちらも精しい泌 尿器科学的検查で尿路系には原因と認定できる異常注証 面されず，ただ夜間の遺尿だけを主訴するものであつ た。この 2 例に怙ける sphincterometrogram 虫正常女 子のそれと同じであつた。

(vii) 無抑制膀睄

神経因性膀胱の一典型でその臨床症状注真性尿失禁 と 同じであるが，ただその原因となるものが中枢神経系に 発生しているものである. 検査の対象となつたのは 3 例 (26才，42才，および44才の女子).第 1 例恣春能損傷に よるもので $\left(\mathrm{Th}_{12}\right.$ 以下の完全麻痷), 排尿困難昖よび残尿 はない. 第 2 例注腦腫瘍（その部位は中脳と推定されて いる）の患者で，完全尿失禁状空呈して抢り，大体50cc の尿が膀胱にたまると, 痤孪性に不随意の膀胱収縮を起 す. 第 3 例快上顎癌の脊䯣転移により $\mathrm{L}_{1^{-3}}$ 以下に不完 全麻瘦を来たしたものである.

第20旵 無抑制膀脱 (脳腫瘍), 42 才 $60 \sim 120 \mathrm{~mm} \mathrm{Hg}$, V 型

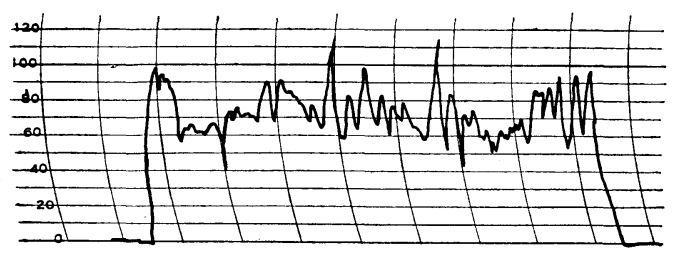

第 1 例の sphincterometrogram $160-120 \mathrm{~mm} \mathrm{HgVI}+$ $\mathrm{IV}$ 型. 第 2 例の sphincterometrogram $460-100 \mathrm{~mm} H$ と緊張度がかなり高い潘か, 波高の変動汸なり大きく 全体として不規則なしかも周波数も多い波型を呈して打 り，著者のいうV型に属するものと考えられる（第20図 参照).この波型が，不規則なのは膀胱内圧測定からも明ら かなよらに少量の尿がたまると急に tenesmus 様に膀 胱が収縮し，そのため不随意に注入した水を漏洩するた めで、緊張度之のものはむしろ昂進していると考えられ
第21図無抑制膀脱（癌転移，の不完全麻瘦）26才 40-90 120mm V Hg VI 型

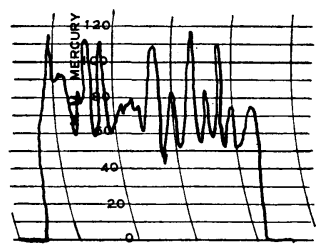

（註）第20図，第21四ともに測定中漏水があり，横 軸は正確な膀腅容量を示さない。

るものであつた。第 3 例の sphincterometrogram も40 〜90 $120 \mathrm{~mm} \mathrm{Hg}$ と非常に測定值の高下が著明で, 波型も 20〜30〜 50 mm Hg と波高の変動が著明である. しかしその 周波数は $4 \sim 5{ }^{\circ} \mathrm{C}$. P.m. と比較的緩かでV V VI型に相 当するものであつた (第21図参照).全般的にいえば無抑 制膀胱という神経因性膀胱のsphincterometrsgram は, 測定値の変動が大きくて最高值も高くむしろ緊張過度 (hypertonic) であり, その波型も波高の変動がかなり 大きく波型も鋭く、VあるいはV型という他の疾患では 汪とんど見られないような波型を呈するのが特徴的とい える.

(viii) 急性膀胱炎

この検査対象は 4 例（18才〜49才）である. 全例とも 程度の差はあるが、測定中に疼痛を訴えるものもあつて 完全に最後まで測定を行い得なかつたものもある．との sphincterometrogram は全体として最高值が80〜90 $100 \mathrm{~mm} \mathrm{Hg}$ ( 1 例では $120 \mathrm{~mm} \mathrm{Hg}$ ), 最低值が70〜 $80 \mathrm{~mm} \mathrm{Hg}$ と一 般緊張過度 (hypertonic) を示して抢り, 波型も波高

第22図・急性膀腅炎，32才80〜 $115 \mathrm{~mm} \mathrm{Hg} ， \mathrm{~V}$ 型（ま たは I + V 型）

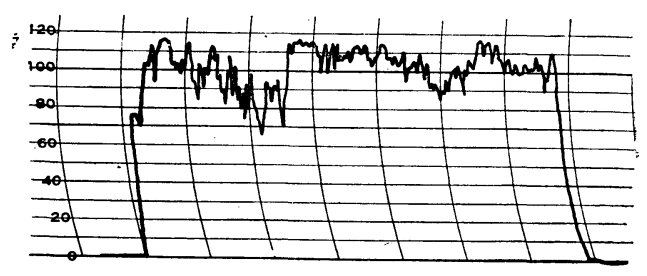

が 10〜 $15 \mathrm{~mm} \mathrm{Hg}$ と変動がかなり著明で周波数も5〜8〜10 c.p.m., 先端の尖つた急激な波型で $\mathrm{V}$ 型に属する波型を 示す傾向がある(第22図参照).

(ix) 萎縮膀胱 (膀睄成形手術後)

結核性萎縮膀胱で膀胱容易50 $60 \mathrm{cc}$ ののに対し膀胱 成形手術を行つた 3 例（30才，40才，41才）が検查対象 となつている. このうち 2 例は回腸膀胱成形術 (ileoc- 
第23図 萎縮膀胱 (回腸膀胱形成術後), 40才 120～ $130 \mathrm{mmHg}, \quad$ III $\sim \mathrm{IV}$ 型

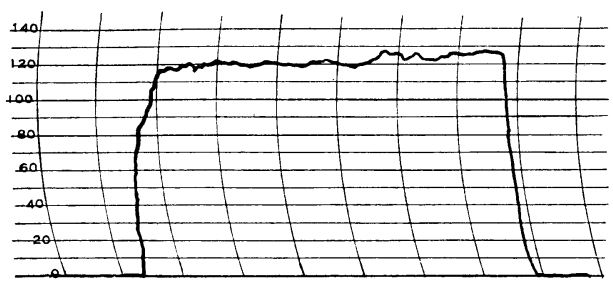

第24図 ラボナール麻酔と sphicterometrogram 35才（正常女子）

(a) 麻酔前

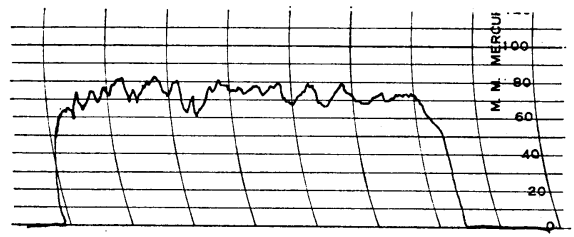

(b) 深麻酔

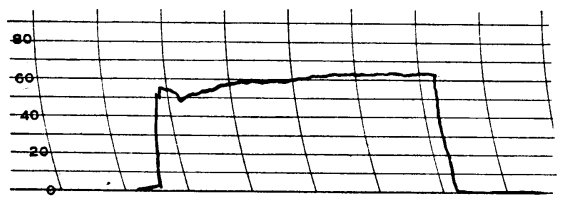

（c）浅麻䣲（や>覚醒した時）

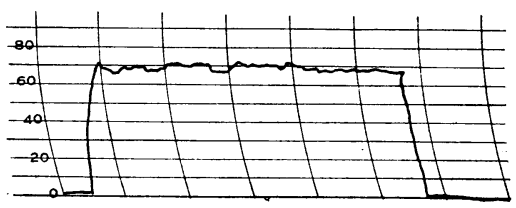

ystop lasty)，1例结結腸膀胱成形術(colocystoplasty)

を施行したものである. 全例とも膀胱容易は 200〜 400 cc と増加し頻尿も著明に改善されているが, な掞ある程 度の排尿困難之 $100 \sim 150 \mathrm{cc}$ 前後の残尿を示していた. その sphincterometrogram は 3 例之も大体同様で, い ずれも最高值は 110～120mm Hg以上に上昇し非常な緊张 過度 (hypertonic) 杂示しているが, 波型としてはむし ろ波高の変動は少なくかなり平坦に近いもので III ～IV 型 に属する波型と考えられる。その1例（40才，回腸膀 睄成形術) の sphincterometrogram を示す（第23図参 照).

（x） sphincterometrogram への麻酔の影響
麻酔法としてはラボナール (thiopental sodium) 静 注による全身麻酔, 脊䯣麻酔 ( $0.3 \%$ percamine S) あ るいは硬膜外麻酔 ( $2 \%$ Xylocaine) によつた.いずれ も麻酔前に既述の方法で膀胱内圧測定孔よび sphincterometry字行い, 麻酔した後に同様の測定を実施した。 また麻酔後15分，30分，60分と時間の経過にしたがつて 測定への影響を追求したものもある.

(a) ラボナール麻酔

ラボナール麻酔の sphincterometrogram への影響の 有無を検查したものは 8 例（正常女子 2 例, 萎縮膀胱 1 例, stress incontinence 1 例, 神経因性膀胱 3 例, 女 児 2 例) である.な打麻酔の深度は意識, 疼痛に対する 反応, 瞳孔、その光反射，呼吸の型：血圧を標準にして 浅麻酔, 適麻酔, 深麻酔と判定した. ラボナール麻酔の sphincterometrogram への影響は症例によつて必ずし も同一ではないが，その1例を示す（第24図a,b,c). と の症例は35才の正常の女子でそのsphincterometrogram も正常な型式を呈しているし第23図 a). ラボナール注 射で適麻酔になると測定值は麻酔前にくらべて 5 〜 $10 \mathrm{~mm}$ Hg程度の低下を示すが波型には鹿とんど変化はない.と とろが深麻酔になると $15 〜 20 \mathrm{~mm} H \mathrm{~g}$ とかなり著明の低下が 生じ, 波型も波高の変動が汪とんどない平坦なものとな る (IV 型に近づく、第 24 図bを参照).浅麻酔となり，や >覚醒した状態になると, 測定值は麻酔前ほどではない が再び上昇の傾向を示すが, 波型はなお波高の変動にそ しいかなり平坦である（第24図c）．他の疾患の場合にも 程度の差はあるが, ラボナール麻酔によつてほぼ同じよ うな影響をうける傾向を示している.ただ萎縮膀胱でも ともと 100 ～120mg と緊張過度だつた 1 例では深麻酔で も依然として同様の高値で低下を生じていない（24図を 参照)。

なお，上述した女児の 2 例 (4才，6才）もラボナー ル麻酔下に測定を行つた. 浅麻酔での sphincterogram はいずれも20〜 30m $\mathrm{Hg}$, 波型は平坦であつた（IV 型に近 いもの).しかし, 麻酔前の測定は不可能だつたので麻酔 前後の sphinctormeirogram は比較できなかつた。

(b) 腰椎，仙骨掞よび硬腰外麻酔

これらの麻酔下に sphincterometry を行つたのは12 例（正常 8 例, 神経因性膀胱 4 例）である. ごちらの麻 酔でも皮膚知覚帯の麻痺が発現固定してから測定を開始 した. 麻酔部位の高さによる sphincterometrogram へ の影響は以下のような成績を示した。

正常女子の場合 $\mathrm{S}_{3}-\mathrm{S}_{4}$ 以下の麻酔によつて, 1 例のみ 
第25図 脊椎麻酔と sphiecterometrogram 40 才(正 常女子）

(a) 麻酔前

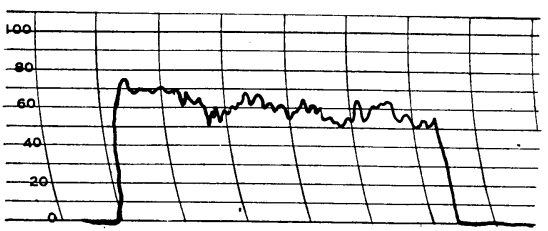

(b) $\mathrm{Th}_{11}$ 以下の麻酔

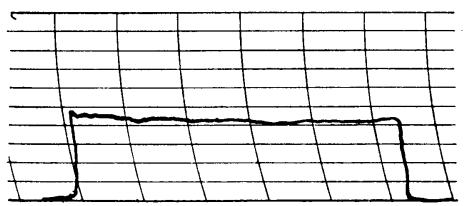

測定值の軽度な低下が生じたほか sphincterometrogr am には全体として医とんど認められなかつた。しかし $\mathrm{S}_{1} \sim \mathrm{S}_{2}$ 以下の麻酔では $10 \mathrm{~mm} \mathrm{Hg}$ 程度の低下と波型の平坦 化を来たすものが大部分で，少くとも $\mathrm{S}_{1} \sim \mathrm{S}_{2}$ の麻酔で は sphincterometrogram にある程度の影響を与えるも のである. $\mathrm{Th}_{10} \sim \mathrm{Th}_{12}$ 以下の麻酔になるととの影響は さらに顕著となり，15～20 $\mathrm{mm} \mathrm{Hg}$ とかり大巾の低下があ り，同時にはつきりした波型の平坦化が認められた（第 25図a,b,参照）。ことにこれらの1例に抬いて祦、測定 中にせきをさせると相当に強い尿失禁を起しているとと が判明し，上位脊䯣の麻酔ほど明かに緊張低下 (hypotonus）を発生させるととを示している.

子宮剔除後の神経因性膀胱に対する脊椎麻酔の sphincterometrogram に対する影響も, patter としては正 常例とほ汸同様であつた。しかし，個々の症例によつて 多少ちがつているととろがあつた。たとえばその1例 ては $\mathrm{Th}_{12} \sim \mathrm{L}_{1}$ に硬膜外麻酔を行つて測定したとこ ろ sphincterometrogram では $5 \mathrm{~mm} \mathrm{Hg}$ 以内の程度の低下 が見られた以外にばはきりした変化は認められなかつ

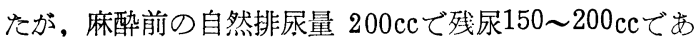
つたのに自然排尿が全く不可能となり，次に $\mathrm{S}_{2}$ 以下の 麻酔では逆に自然排尿はむしろ円滑となり, 残尿は50cc 程度に娍少している.な招本例は膀胱充満结全く消失し ている患者である. 他の 1 例では $\mathrm{Th}_{11} \sim \mathrm{L}_{1}$ の麻酔によ つて, 麻酔前の sphincterometrogram 低下があり，波型IV 型で平坦に近かつたものが，測定值 には恬とんご変化がなかつたにもかかわらず尿失禁状態 を呈した。との 2 例は一見全く矛盾するような現象を州
しているが，後者の症例では麻酔前の膀胱内圧曲線は緊 張過度であり，麻酔後はさらに緊張度が昂進を示してお り, 恐らくこのために尿失禁状態を呈したものと考えら れる、したがつて両側とも脊椎麻酔, とくに比較的高位 の麻酔によつていずれも緊張度低下を発生したものと推 定してよいと思われる.

\section{IV. 総括と考察}

前章までに記述したような測定装置と測定法によつ て, 正常女子抬よび排尿異常を主症状とする女子尿路疾 患々者についてその sphincterometry を行つた結果, それぞれに比輘的特有と考えられる sphincterometrogramのパターンを得，との測定法が臨床的に十分応用し 得るととを認めたものである．以下とれらの測定成績を それぞれについて総括するとともに，その臨床的な意味 に関して若干の考察をも行うことにする.

第 3 章で述べたように, 著者はこの測定によつてつく られた sphincterometrogram の分析に当り，水圧の示 す測定值と波型という２つの要素を組合わせた．との測 定值とは, ポンプ装置により一定の流速（流量, 著者の 装置では毎分50cc）で外尿道口から注入した滅菌水の水 圧がまず一定量の流入後に上昇してある時間はほぼ同じ 高さにあり，しかる後にまた0の位置に低下した時まで の水圧のととを指すのである. 0 の位置に水圧が復帰し たの以注入された水が内尿道口から膀胱内に連続的に流 入していくためである。つまり，乙の上昇した水圧は外 尿道口から内尿道口（膀胱顤部）までの筒状をした女子 尿道の能動的拈よび受動的な抵抗，いいかえると緊張度 を反影しているものと考えるととができる。したがつ て、括約筋という特定な部位の筋の緊張度だけを測定し ているとと解釈されやすい sphincterometry という用 語は必ずしも適当とはいえない。もちろん，この装置に よる sphincterometry が外括約筇の緊張度をも測定し ているととは確かであり，恐らくその示す抵抗の最大の 要素と考えられるが, それ以外にも約 $2 \sim 3 \mathrm{~cm}$ 長さを 有する女子尿道を構成している他の等組織あるいは結合 組織などの緊張度をも同時に測定しているからである. したがつて, 著者嵃この sphincterometry という測定 法学, 外尿道口から内尿道口（膀胱澒部）に至る尿道内 腔が注入された水によつて拡張される時に生ずる全抵抗 (主たる るもの恬約筇) を水圧として総合的に測定して いるものとする，ᄃの場合著者はこの抵抗 (resistance) を一応緊張度 (tonus) とよぶととにした。あるいは Iapides（1962）などが使用しているようにとれを 
sensitivity とよんでもよい。そして著者はこの緊張度 の強弱によつて緊張過度 (hypertonic), 正常 (normotonic), 緊張低下 (hypotonic) に分けたが，との強弱は :sphincterogram の圧の高低によつて示されるわけであ る.

もう 1 つの要素である波型は，既述のように波の性状 （波高，波形，周波数など）によつててれをI 型からVI 型に分類した。 との波型がどうして発現するか，その関 与する因子は単一なものではないと考えられるので正確 な判定は不可能である.

しかし，乙の波型の一部，とくに比較的大きな波は恐 らく強く伸展された筇層の収縮によつて生ずるものと考 えられる。

つまり、はつきりした波型を伴つている sphincterometrogram 以等層（とくに外括約筇）の緊張度が十分 保持されているか, あ吕い性過度に高まつている (hyp.ersensitive) ことを示しているといえょう。

次にとの sphincterometry による成績を総括し同時 にその解釈について考察を行つて見る.

（1）正常女子の sphinetərometrogram

いろいろな病的状態の sphincterometrogram を解釈 する基準とするのが正常者の場合のそれであるのはいう までもない(第 8 図，第 9 図学参照). 正常女子の sphincterometrogram红扮ける測定値（水圧）の最高, 最低 の分布注第10図に示すようにある程度の範囲内に分布さ れている．例外的に $120 \mathrm{~mm} \mathrm{Hg}$ 何上を示すものもあるが。 そのほとんど全部が40～ $80 \mathrm{~mm} \mathrm{Hg}$ 範囲内にある.したが つて基準としてはとの範囲を正常 (normotonic) とし てよいと考えられる。ただしとれをはずれたものをすぐ に膀胱過度 (hypertonic) あるいは緊張低下 (hyphtonic）だと速断することはできない，正常でも $35 \mathrm{~mm} \mathrm{Hg} \sim 90$ $\mathrm{mm} H \mathrm{~g}$ 以上のものが例外的にも存在するからである.した がつて, 正確な判定には他の検査所見をも考慮しなく てはならない。しかしごく一般的にいえば， $100 \mathrm{~mm} \mathrm{Hg}$ 上のものは緊張過度, $30 \mathrm{~mm} \mathrm{Hg}$ 以下の場合は大よそ緊張低 下と見てよいようである.

正常人の sphincterometrogram に怙ける波型はかな り一定している.すなわち，かなりはつきりしているが それ医ど高くなく中等度の周波数をもつた波高のもの办

(I 型，40例中22例)，波高はむしろ低くてそれに従 つて周波数はや〉多くなつたもの（III 型，40例中11例） が大部分である(第 8 図, 第 9 図参照).波高の変動の大 きなものとか (II 型，V 型，VI型),逆に涹とんど変動の
ない活とんど平坦に近いもの（IV型）は絶無ではないが 例外的にしか発現していない，な技，10才以下の正常女 児では測定実施が案外困難なため, 10〜13才の 3 例だけ にしか sphincterometrogramが得られなかつた。この 思春期前後の女児の sphincterometrogram 流成人女子 のそれに比して值がや〉低く，波型も平坦に近い傾向を 示しているょうである.

（2）真性尿失禁

2 例だけであるが，完全な尿失禁という臨床症状に対 応していずれも著明な緊張低下があり，波型は平坦であ る.

(3) stress incontinence

外国では女子の泌尿器疾患としてかなり重要なものの 1つで，との診断とか治療については多くの報告がある が(Marshall, Marchetti, Kranz, 1949 : Muellner, 1962 : その他)，わが国での関心はまだ低い。著者がとの研 究を企図した理由の 1 つも，実效との stress incontinence の診断 (とくに程度の判定) とかく治療法の評洒に 役立たせたいという点にあつたわけである. この15例に 扮ける測定成績は尿失禁の程度によつて必ずしも一定し てはいなかつたが，全体的にいえば次のように要約でき

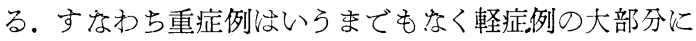
执いても40〜 50 $\mathrm{mm} \mathrm{Hg}$ あるい注50〜60 $\mathrm{mm} \mathrm{Hg}$ 示示し, 最低值 は大体正常範囲内にあるが最高值牥一般にや>低い（軽 度の緊張低下) 傾向を呈している. 波型山過半数の 9 例 が平坦なIV 型， 4 例がこれに近いIII 型を示している。し かしI 型乃至II 型のものも数例あり，とれらは測定值も 正常 (normotonic, $65 \sim 80 \mathrm{~mm} \mathrm{Hg}$ ) 加しろや>緊張過度 （75 90m Hg）のものもあつた. しかも緊張度正常ある いはや>緊張過度のものでは, 軽度ながら慢性膀胱炎を 思わせる所見をもつていることが確認された。つまり， stress incontinence のうちには, sphincterometrogram でや>緊張低下を示すものと, sphincterometrogram 注添洼正常でありながら恐らく膀胱(顏部を含めて) の過敏状態が主因となつて部分的尿失禁を起すものの 2 種類があると考えられる．実際にも著者例のうち後者は 治療による炎症所見の消失とともに症状はかなり改善さ れている.このような鑑別あるいは治療法の撰択には， この sphincterometry が有用であるということができ る.

（4）神経因性膀胱

子宮癌のために広汎性子宮剔除術を施行された後に膀 胱の機能障害を発生する頻度は, 正確な数字は不明であ 
るが案外に少なくないととは確かといえる。これは骨盤 内の広沉な手術操作のため, 膀胱への末梢神経が損傷さ れて発生したと考えられるもので, 神経因性膀胱の範疇 に含ま礼る障害である。そ臨床症状は著者の症状にも 見られるように，自覚的あるい礼他覚的にもかなり複雑 で，もちろんその程度もいろいろである。しかし、多く の場合乞の症状は膀胱充満感の欠如, 排尿困難 (したが つて種々の程度の残尿を伴引），時にはいわゆる overflow

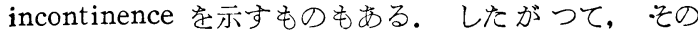
sphincterometrogram も具体的な面でかなり多様性安 呈することになる。（第 2 章のIV）をも参照).ただ全般 的にいうと,乙の神経因性膀胱の sphincterometrogram は最高值がや>低下を示して抢り，波型も平坦な $\mathrm{N}$ 型 のものが多い. との点は stress incontinence に近い といえるが，前者においては最低值はどちらかというと 後者より高い值を示している．またての神経因性䏽睄で は, 測定值の変動が添とんどないという点も特典的とい える。

ところが, sphincterometrogram が緊張低下に傾い ているのに，民゙うして排尿困難が起るのであろらか．第 1に考えられることは，著者の装置による sphincterometry は既述のように主として外尿道口名ら内尿道口に 至る尿道の抵抗（緊張度）定総合的に逆行性の注水によ つて測定するもので, 内尿道口部の緊張度あるいは開放 機能だけをとくに測定しているわけではない，したがつ て, この sphincterometry で内尿道口部の機能を直接 に推定することは無理である。しかし， sphinecterometryではむしろ緊張低下に傾いているのに，排尿困難が あるというととは, その主たる原因が内尿道口の変化(内 尿道口部の開放機能の不全) によるものであることを 間接的に推定できる 1 つ傍証というととができる。い い心元ると， sphincterometry によつて，子宮剔除術 後の神経因性膀胱の狭窄は主として内尿道口部にあるこ とが証明されたうけである。.とのととはとの神経因性膀 胱の排尿困難が膀胱頚部の組織切除（経尿道的あるいは 経膀胱的）によつて全く市るいは著明に改善されるとい う臨床治療にも対応するものである。ただし， sphincterometry では緊張低下の傾向のととが多いから，膀胱 䅡部の切除が大きすぎると stress incontinence を続 発する伦険もそれだけ大きいことになる。乙の点も実際 の臨床治療成績で往々見られる事実である.

な扮，ての神経因性膀胱では一種の overflow incontinence を同時に伴つているととがある。しかし，尿失
第 26 図

（a）神経因性膀胱（子宮剔除後）の膀腅内圧曲線， 47 才

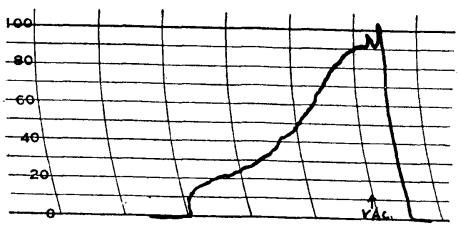

（b）神経因性膀脱（子宮剔除後）の膀胱内圧曲線， 50 才

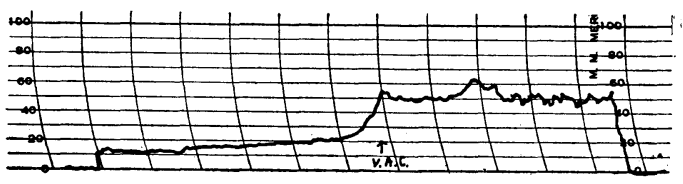

禁は必ずしも残尿が多量でなくても発生する。 ての点に 関して興味のあるのはこの神経因性膀胱における膀胱内 圧測定の成績である。著者の行つた測定結果によれば， そのほとんど全部はいわゆる緊張過度膀胱の内圧曲線を 示していた. しかもその多くのものにおいてその内圧曲 線はかなり特有である.すなわち膀胱への注水量が少な いうちは正常 (normotonic) かや>緊張過度 (hypertonic), 時に怯むしろ緊張低下 (hypotonic) でありなが ら, 注水量がある一定量 (これは個々の症例でちがう) を越えると，急に著明の緊張過度を示し内圧は急上昇す る（第26図a,b）。そしてての時に尿の漏洩が起る。いわ ゆるVAC (voiding around catheter) である.との ような sphincterometrogram と膀胱内圧曲線 (cystometrogram) の型式を示すものは, 従来の神経因性膀胱 の分類にははいつていない (Munro, 1936 : Mclellan, 1939 : Scott 1954など).たとえば Scott (1954) のいう sensory neurogenic blodder $は$ 膀睄内压曲線からは atonicであるが，乙の神経因性膀胱は hypertonic である からである。強いていえば自律性膀胱 (automatic blodder) に近いものかも知れない.いわば stress inconti nence と無抑制膀胱の混合型ともいうべき特殊な典型と む考えられる。

（4）夜尿症

既述のように，小児では正確な測定ができず，2 例の 夜尿症についてだけ実施された。症例が少ないので断定 はもちろんできないが、夜尿症に打ける sphincterometromgram は正常女子のそれと全く同様であつた。 
（5） 無抑制膀胱

との型の神経因性膀胱は上位ノイロンの障害によつて つくられたもので，著者の測定したのは 3 例である。 と の無抑制膀胱における sphincterometrogram の特長 は、いずれも測定值が高く(緊張過度) しかもその波型 も波高の変動が著明で、著者のいう V、VI型を示してい た。 また同時に測定した膀胱内圧曲線も子宮剔除術後の 神経因性膀胱に見られたと同じょうに，緊張過度 (hypertonus）を示しており，膀胱に一定量の水（あるい梳 尿）がたまると急激に不随意的にこれを排出する.

（6）急性膀胱炎および萎縮膀胱

急性膀胱の 4 例では，いずれも測定值の最高おょび最 低值が高くてかなり著明な緊張過度の状態にあるほか, 波高も10 15mm Hgで周波数の多い波型を示している. 恐 らく炎症によつて膀胱頚部を中心とする部位が 過敏性 (hypersensitive) になつているためと考えられるもの で、実際にも測定に当つて疼痛定訴えることが往々あつ た.

結核性萎縮膀胱で膀胱成形手術を行つたもの 3 例に抢 ける sphincterometrogram は, 測定值の最高が異常に 高くて (110〜 120mm Hg) 強い緊張過度を示しているの に対し、波型はむしろ平坦に近いものであつた。 ただ し、とれら症例は㓐からの触診, 尿道鏡あるいは膀脱鏡 所見によると，いずれもその尿道は固有の弾力性が低減 乃至消失していて，恰かも硬い筒を思わせる性状であつ た.したがつて、とれらの sphincterometrogram が緊 張過度を示しているのは, 器質的病変が確立されて尿道

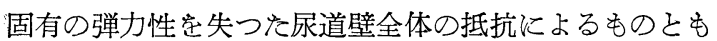
思われる.ラボナール麻酔下に測定を行つた 1 例に执い て、一般には低下するはずの測定值に法とんぞ影響がな かつたことからも，このととが推定できる.

（7）麻酔の影響

ラボナール麻酔、または脊䯑嗵麻酔を正常者および各種 の排尿異常症に施した前後の sphincterometrogram を 比較した.

ラボナール静注による全身麻酔では適麻酔から深麻酔 に及ぶと、上述した萎縮膀胱の 1 例を除き，他のもので は正常 (normotonic) あるいは緊張過度 (hypertonic) いずれにおいても，測定值の低下（ただし低下の程度は 一定していない）を来たし波型も平坦化する.

春椎麻醉では部位によつて影響に差がある。たとえば $\mathrm{S}_{3}-\mathrm{S}_{4}$ の麻酔では全体としての sphincterometrogram

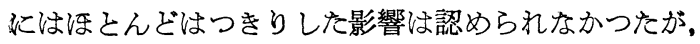

$\mathrm{S}_{1} \sim \mathrm{S}_{2}$ の麻酔で注測定值の低下（緊張度の低下）が生 ずる.しかし波型への影響证起つていない，ところがさ らに高位の $\mathrm{Th}_{10} \sim \mathrm{L}_{1}$ 以下の麻酔ではかなり著明な影響 があり、測定值㤝大よそ10２0 $\mathrm{mm} \mathrm{Hg}$ と大巾の低下を来た し，同時にその波型の平坦化する傾向を示していた。 こ の高位脊椎麻酔による sphincterometrogram の変化 は，正常のみならず神経因性膀胱に沶いても認めら机て いる.

したがつて、 sphincterometry 行う場合, ラボナ ールなぞによる全身麻酔はその sphincterometrogram に影響を与える可能性が強いから，原則として恃行わな い方がよい，ただし，既述の萎縮膀胱の場合のように尿 道の器質的病変が主かどうかの鑑別には役立つことにも なる. 脊椎麻酔は $\mathrm{S}_{3} \sim \mathrm{S}_{4}$ 部位であれば sphincterometrogramにはまず影響を及洼さないが、それより高位の 春椎麻酔では緊張低下という影響が生ずるから注意を要 する。

\section{$\mathbf{V}$ 結 論}

著者は外尿道口に接着させた特殊のスポイト(アダプ ター）を通し流量計を具えたポンプから一定流量（毎分 $50 \mathrm{cc}$ ）の温水を尿道から膀胱に流入させる sphincterometer を作製し、とれに連続自動記録器を連結させて女 子に扮ける sphincterometry 行い，臨床的浰用し 得る検査法であることを認め得た。 との測定法による sphincterometrogramの成績は以下の如くである。

（1）正常女子の sphincterometrogramに执汸緊 張度 (測定值) は添ぼ40〜80 mm Hgの範囲内にあり, 波型 （波高の上下，周波数）浪や〉多い周波数と大きくはな いが明膫な波高の上下を示しているI 型か，とれより周 波数牥多いが波高のより低いII 型を示している. 正常女 児での緊張度は一般に成人に比してや>低い。

（2）真性尿失禁では緊張度（高值も最低值も）の著 明な低下と平坦な波型を示している.

stress incontinence は症状の程度によつて一定しな い. 重症のものの sphincterometrogram は真性尿失禁 のそれに近い型式である。より軽症の大部分に揖いては 最低值は潘正常だが明らかに最高值の低下，したがつ て緊張度の低下傾向を示して扔り，波型はどちらかとい 万と平坦かそれに近いものが多い，しかし軽症でしかも や>緊張過度を呈するものもあり，てれらでは程度の差 はあるが膀胱䅡を中心とした炎症を伴つている点が特有 である、との点は stress incontinence の治療法を選 定するのに役立つ. 
（3）広沉性子宮剔除術後に発生した神経因性膀胱の sphincterometrogram はある程度の多樣性を示してい るが、大多数では最高值の低下と平坦な波型を示す傾向 がある.とれ机 stress incontinence のそれと類似て いるが，これでは最低值は全く低下していない。また一 般に sphincterometrogramの動摇極めて少い。それ にもかかわらず排尿困難导主訴とするのは，すでに膀胱 頝部に何らかの器質的変化が発生し開放機構の障害が存 在するためと考えられる。したがつて，緊張低下ではあ るが膀胱澒部の切除術が有効である。もう 1 つの特徵は この全部が膀胱内圧測定で緊張過度を示しているとと で, 部分的尿失禁往及訴えるのはこのためと考えられ る. このょうに膀胱内圧曲線掞よび sphincterometrogram ふら見て，乙の神経因性膀胱は純粋な stress incountinence あるいはいわゆる sensory neurogenic bladder (atonic bladder) ともちがう, 特殊の一型と考え るととができる。

（4）夜尿淀の sphineterometrogram は正常であつ た. 無抑制膀胱の sphincterometrogramは緊張過度と 波高上下の顕著な波型を示した。

（5）急性膀胱炎では炎症による己考えられる過敏性 状態を示す sphinctemetrogram が得られた。膀睄成形 術を行つた結核性萎縮膀胱はかなりの緊張過度と平坦な 波型をもつ sphincterometrogramを示したが，との緊 张過度に麻酔によつても低下宅来たさない。

（6）ラボナールによる全身麻酔では，萎縮膀胱例を 除き、いずれにおいても程度の差牥あるが緊張度の低下 と波型の平坦化が認められた。春椎麻酔は部位により異 なり、 $\mathrm{S}_{3} \sim \mathrm{S}_{4}$ では㴗とんど sphincterometrogram に 影響はないが, $\mathrm{S}_{1-2}$ 以上では緊張度の低下と波型の平坦 化を来たし、その程度は高位脊椎麻酔流ごはつきり発現 する傾向を示した。

\section{文献}

1) Arnold, J.H.: J. Urol., 8, 651, 1959.

2) Beck, L.: Geburtsh. Frauenheilk., 21, 44, 1961.

3) Bors, E.: J. Urol., 60, 287, 1948.

4) Emett, J.L.: Campbell's Urology p. 137, W.B. Saunders Company, Philadelphia and London, 1963.

5) Enhöhrning, G.: Acta Chir. Scand., Suppl.
$276,1961$.

6) Hartl, H.: Geburtsh Frauenheilk., 13, 136, 1953.

7）猪野毛健男：日泌尿会誌，55，1012，1964.

8）伊丹昇：日泌尿会誌，37, 7, 1946.

9）伊丹昇：日泌尿会誌，37, 10, 1946.

10）近藤賢：日泌尿会誌, $55,607,1964$.

11）加藤篤二：日本泌尿器科全書第 5 巻, 175 頁, 昭35. 日本泌尿器科全書刊行会, 金原出版, 東 京.

12）小林隆：子宮䅡癌手術, p. 460 , 昭 37 , 医学書 院, 東京.

13) Lapides, J.: J. Urol., 84, 86, 1960.

14) Lapides, J.: Surgery etc., 114, 241, 1962.

15) Lapides, J.: J. Urol., 91, 58, 1964.

16) Lewis, L.G.: J. Urol., 41, 638, 1935.

17) Marshall, V.F., Marchetti, A., \& Krantz, K.E.: Surgery etc., 88, 509, 1949.

18) Milan, D.F.: J. Urol., 84, 433, 1960.

19) Muellner, S.R.: J. Urol., 86, 473, 1958.

20) Muellner, S.R.: JAMA., 172, 1256, 1960.

21) Muellner, S.R.: JAMA., 174, 843, 1961.

22) Muellner, S.R.: Surgery etc., 114, 568, 1962.

23) Mclellan, FIC.: The neurogenic bladder, C.C. Thomas, Springfield, Illinois, 1939.

24) Munro, D.: New England J. Med., 214,617, 1936.

25) Murphy, J.J.: J. Urol., 84, 106, 1960.

26）中島交雄: 日泌尿会誌, 51, 264, 1960.

27）中野修道：日泌尿会誌，54, 858, 1963.

28）落合京一郎：臨床皮泌，9,1218，1955.

29) Plater, H.: Z Zbl gynäk., 81, 250, 1959.

30) Rose, D.K.: JAMA, 88, 151, 1927.

31）佐藤誠：日泌尿会誌, $29,565,1940$.

32）佐藤誠：日泌尿会誌， $31,176,1941$.

32) Simons, I.: J. Urol., 35, 96, 1936.

34) Scott, W.W.: Year Book of Urology, 220, 1954-1955.

35) Thiermann, E.: Zschr, Urol., Uerh, Ber, 1951.

36）土屋交雄：日泌尿会誌，54，659, 1963.

37) Woodburne, R.: Anat. Rec., 141, 11, 1961.

38) Wondburne, R.: Surgery etc., 113, 487, 1961.

39) Young, B.W.: Surgery etc., 113, 62, 1961.

40）山村秀雄: 臨床麻醉学, 昭38. 医菌薬出版, 東 京.

（昭和 40 年 4 月 1 日受付） 